\title{
AUDITORIA INTERNA: SUA IMPORTÂNCIA NAS ORGANIZAÇÕES EMPRESARIAIS NO ÂMBITO COMPETITIVO
}

\author{
Erica Aparecida Hott ${ }^{1}$ \\ Edevaldo de Castro Monteiro²
}

Resumo: A auditoria interna passou a ser um instrumento de amplo controle para os gestores, através de atividades que auxilia a administração como meio de identificar que os processos internos e políticas definidos pela companhia, assim como sistemas contábeis e de controle interno, estão sendo efetivamente seguidos e que as transações realizadas estão refletidas contabilmente em concordância com os critérios definidos previamente, permitindo-Ihes exercer com segurança o processo decisório sobre as importantes transações empresariais, sendo um diferencial no meio competitivo. Neste contexto, o presente trabalho teve por objetivo apresentar a importância da auditoria interna dentro do âmbito organizacional nos dias atuais. Utilizou-se uma pesquisa descritiva, com base em estudos publicados que abordam o tema central deste estud. Conclui-se que a organização que investir na contratação do auditor interno terá mais chances de se alavancar no mercado competitivo diante dos avanços econômicos.

Palavras-chave: Auditoria; Gestão eficaz; Processos organizacionais; Tomada de decisão.

\footnotetext{
${ }^{1}$ Ciências Contábeis/Faculdade do Sudeste Mineiro - FACSUM, Brasil. E-mail: ericaphott@gmail.com.

2 Engenharia Agronômica/Universidade Federal Rural do Rio de Janeiro - UFRRJ, Brasil. E-mail: ecmonteiro@hotmail.com.
} 